\title{
Studies on the intestinal flora ${ }^{1}$
}

\section{Part II Bacterial flora of the small intestine in patients with gastrointestinal disorders}

\author{
B. S. DRASAR AND MARGOT SHINER \\ From the Department of Microbiology, Wright-Fleming Institute, St Mary's Hospital, and \\ The Medical Research Council Gastroenterology Unit, Central Middlesex Hospital, London
}

\begin{abstract}
SUMMARY The type and distribution of bacteria in the jejunal juice of patients with a variety of gastrointestinal conditions that might affect the small intestinal flora were examined.

Bacterial colonization of the jejunum defined, in this context, as the occurrence of a bile salttolerant flora consisting of both aerobic and anaerobic bacteria qualitatively resembling that of faeces, was observed only in patients with some form of blind loop. Prominent among the bacteria isolated from these colonized juices were non-sporing anaerobic bacteria, most usually Bacteroides, able to hydrolyse bile salts.

No simple correlation between the patient's fat excretion and bacterial colonization of the jejunum could be demonstrated.
\end{abstract}

The normal bacterial flora of the human alimentary canal has been described in a previous paper (Drasar, Shiner, and McLeod, 1969) in which we stressed the need for complex bacteriological techniques for the isolation of the dominant oxygen-sensitive anaerobic bacteria. In this paper we present our results on the flora of the upper jejunum in fasting patients with a variety of clinical conditions that might affect the small intestinal flora.

Dawson and Isselbacher (1960) were the first of many to suggest that the steatorrhoea associated with blind loops of intestine is due to the bacterial degradation of bile salts within the loops. We have attempted, therefore, to discover whether there is an association between steatorrhoea and colonization of the jejunum, and also to assess the ability of bacteria isolated from the intestine to degrade bile salts.

\section{METHODS}

Jejunal contents were obtained with the use of the capsule described previously (Shiner, 1963). The tube was guided under fluoroscopic observation to the upper jejunum (at the level of the ligament of Treitz) from which samples were collected. In patients who had had a Polya partial gastrectomy, samples were obtained from the efferent loop.

${ }^{1}$ Part I of this paper on the bacterial flora of the gastrointestinal tract in healthy and achlorhydric persons was published in Gastroenterology (56, 71-79).
The bacteriological techniques were the same as those used to investigate samples from normal people. Specimens were transported as a 1/10 dilution in glycerol broth frozen with the help of dry ice. The specimens were thawed immediately before cultivation. Ten-fold dilutions were prepared in oxygen-free agar in an anaerobic chamber (Drasar, 1967). Aliquots were also spread on a series of conventional plates in order to cultivate aerobic and aerotolerant bacteria.

In addition to the bacteriological examination of jejunal samples the following tests were performed on the patients in an attempt to assess their condition more exactly.

1 Gastric $p \mathrm{H}$ was recorded as the most acid value obtained during the histolog test, and achlorhydria was defined as the failure of the $p \mathrm{H}$ of gastric juice to drop below 6.0 .

2 Faecal fat estimations were carried out by the method of van de Kamer, ten Bokkel Huinink, and Weyers (1947). Stools were collected for three days on a ward diet or home diet.

3 In an attempt to determine the degree of bile salt degradation occurring in the blind loops, qualitative analyses of the bile salts present in some of the jejunal juices were performed using thin-layer chromatography. The whole juice was spotted on a $250 \mu$ thick silica gel G plate which was developed and the spots were detected using the system described previously (Drasar, Hill, and Shiner, 1966).

Bacteria isolated from the jejunum of various patients were tested for the ability to hydrolyse sodium taurocholate (Hill and Drasar, 1968). An attempt was made to examine all the bacteria grown from specimens 
containing very few organisms. From specimens containing larger numbers of bacteria six strains of each type isolated were subcultured from the highest dilution at which growth of the particular type occurred. Some of the strictly anaerobic bacteria were lost during purification. Overall approximately $80 \%$ of the anaerobes survived to be tested; however, in some cases survival was as low as $15 \%$ but on no occasion were all the strains lost.

\section{PATIENTS STUDIED}

A total of 113 patients were examined. All patients underwent the usual physical, haematological, biochemical, and radiological examinations. Clinical details of the patients are presented in Table $I$. All patients fasted for at least 10 hours before intubation.

POLYA PARTIAL GASTRECTOMY Of the 43 patients in this group 29 were males, 14 were females. Their ages ranged from 28 to 72 years with an average of 54.4 years. Thirty-one patients had a Polya partial gastrectomy only, five had an additional vagotomy, two had an entero-enterostom, two had a partial pancreatectomy, and one had a Roux-en-Y in addition to the vagotomy. Partial gastrectomy with partial or total pancreatectomy but without vagotomy was carried out in two patients.

Twelve patients were symptomless, 30 patients complained variously of vomiting, dumping, diarrhoea, constipation, epigastric or abdominal pain, and one patient had melaena.

The $p \mathbf{H}$ of the gastric juice was determined in 36 of the 43 patients. It failed to drop below $p \mathrm{H} 6.0$ in 27 patients. Faecal fat determinations were normal in 17 patients (less than $5.0 \mathrm{~g}$ in 24 hours), abnormal in 23 patients, and not determined in three patients.

GASTRIC OPERATIONS OTHER THAN POLYA PARTIAL GASTRECTOMY The 14 patients in this group comprised seven males and seven females, aged 21 to 68 years with an average age of $50 \cdot 1$ years. Five patients had undergone a Billroth I gastrectomy which included vagotomy in one. Four had a pyloroplasty with vagotomy, two had a gastroenterostomy with vagotomy, one had a jejunal replacement operation (Wirts, Templeton, Fineberg, and Goldstein, 1965), and one had a pyloroplasty without vagotomy. One patient had a total gastrectomy. Postoperative symptoms were present in all but two patients and consisted of abdominal pain, vomiting, or diarrhoea. Five of 13 patients were achlorhydric and only four patients had steatorrhoea.

GASTROJEJUNOCOLIC FISTULA Four patients were investigated, three male and one female, aged 47 to 75 years. Two patients had a gastrojejunocolic fistula, one had a gastrocolic fistula, and one a jejunocolic fistula. Gross steatorrhoea was found in all four patients.

BLIND LOOPS The 17 patients in this group comprised 13 males and four females, aged 39 to 78 years. Clinically they formed a mixed group with symptoms ranging from mild dyspepsia, abdominal pain or diarrhoea, to small intestinal obstruction. Fourteen patients had small intestinal diverticula which were single in eight and multiple in six, one had a subacute intestinal obstruction from an unknown cause as well as a single duodenal diverticulum, and two patients had blind loops affecting the ileum. Neither the severity of the symptoms nor the presence of multiple rather than single diverticula correlated closely with the degree of steatorrhoea, except in the most severe cases. Achlorhydria was found in six of 10 patients examined and steatorrhoea was present in seven of 15 patients studied.

REGIONAL ENTERITIS Six patients were studied, three male and three female, aged 19 to 72 years. All but one had previous small intestinal resections, three of the terminal ileum, and two part of the jejunum and ileum. Steatorrhoea was demonstrated in four of the six patients.

TABLE I

\begin{tabular}{|c|c|c|c|c|c|c|c|c|}
\hline \multirow[t]{2}{*}{ Condition } & \multirow{2}{*}{$\begin{array}{l}\text { Total } \\
\text { No. of } \\
\text { Cases }\end{array}$} & \multirow{2}{*}{$\begin{array}{l}\text { Age }(y r) \\
\text { Range } \\
\text { (mean) }\end{array}$} & \multicolumn{2}{|c|}{$\begin{array}{l}\text { PATIENTS STUDIED } \\
\text { Sex }\end{array}$} & \multicolumn{2}{|c|}{ Gastric Acid } & \multicolumn{2}{|c|}{ Three-day Faecal Fat } \\
\hline & & & Male & Female & $\begin{array}{l}\text { No. } \\
\text { Tested }\end{array}$ & $\begin{array}{l}\text { No. } \\
\text { Achlorhydric }\end{array}$ & $\begin{array}{l}\text { No. } \\
\text { Tested }\end{array}$ & $\begin{array}{l}\text { No. } \\
\text { Normal }\end{array}$ \\
\hline $\begin{array}{l}\text { Polya partial } \\
\text { gastrectomy }\end{array}$ & 43 & $\begin{array}{l}28-72 \\
(54 \cdot 4)\end{array}$ & 29 & 14 & 36 & 27 & 40 & 17 \\
\hline $\begin{array}{l}\text { Other gastric } \\
\text { operations }\end{array}$ & 14 & $\begin{array}{l}21-68 \\
(50 \cdot 1)\end{array}$ & 7 & 7 & 13 & 5 & 14 & 10 \\
\hline $\begin{array}{l}\text { Gastrojejunocolic } \\
\text { fistula }\end{array}$ & 4 & $47-75$ & 3 & 1 & 3 & 0 & 4 & 0 \\
\hline Ileal blind loop & 2 & $66-70$ & 2 & 0 & 2 & 2 & 2 & 1 \\
\hline $\begin{array}{l}\text { Diverticulosis } \\
\text { of the duodenum } \\
\text { and jejunum }\end{array}$ & 15 & $\begin{array}{l}39-78 \\
(57)\end{array}$ & 11 & 4 & 8 & 4 & 13 & 7 \\
\hline $\begin{array}{l}\text { Regional } \\
\text { enteritis }\end{array}$ & 6 & $\begin{array}{l}16-72 \\
(39 \cdot 6)\end{array}$ & 4 & 2 & 0 & - & 6 & 2 \\
\hline Pancreatitis & 4 & $\begin{array}{l}26-62 \\
(46)\end{array}$ & 4 & 0 & 0 & - & 4 & $\mathbf{0}$ \\
\hline Coeliac disease & 5 & $10 / 12-16$ & 2 & 3 & 0 & 一 & 5 & $\mathbf{0}$ \\
\hline $\begin{array}{l}\text { Idiopathic } \\
\text { steatorrhoea }\end{array}$ & 6 & $\begin{array}{l}42-76 \\
(59)\end{array}$ & 2 & 4 & 0 & 一 & 6 & $\mathbf{0}$ \\
\hline Diarrhoea & 14 & $\begin{array}{l}24-78 \\
(51)\end{array}$ & 10 & 4 & 0 & - & 14 & 14 \\
\hline
\end{tabular}


PANCREATITIS Of the four patients in this group, two had relapsing pancreatitis and two had chronic pancreatitis with calcification. In all patients the Lundh test showed very low tryptic activity and gross steatorrhoea could be demonstrated.

DIARRHOEA In 13 of the 14 patients investigated for diarrhoea (10 male and four female, aged 24 to 78) detailed biochemical, radiological, and bacteriological investigations were all negative. In the fourteenth patient an infestation with Strongyloides was eventually demonstrated.

COELIAC DISEASE AND IDIOPATHIC STEATORRHOEA Five children with coeliac disease and six adults with idiopathic steatorrhoea were investigated either before or after treatment with a gluten-free diet. In each case the diagnosis had been confirmed before treatment by biochemical and histological investigations.

\section{RESULTS}

BACTERIAL FLORA OF THE UPPER JEJUNUM The results of the bacterial examinations are subdivided into groups according to the patients' condition.

Polya partial gastrectomy The results of the bacteriological examination of 43 patients who had undergone Polya partial gastrectomy are summarized in Figure 1. The samples can be divided, on bacteriological grounds, into three groups. Sixteen samples contained less that $10^{3}$ organisms per gram of juice; these samples were bacteriologically similar to those obtained from normal subjects. Fourteen samples contained between $10^{3}$ and $10^{4}$ organisms per gram of juice; this count is slightly higher than that found in normal people and is of the same order as commonly occurred in samples from achlorhydric patients. Thirteen samples contained more that $10^{4}$ organisms per gram of juice. These samples contained a complex bile-resistant flora qualitatively similar to that found in normal faeces and thus indicative of an established ecosystem.

These bacteriological groups bore no obvious relationship to gastric acidity. The gastric $p \mathbf{H}$ readings found in these three groups of patients are presented in Fig. 2 and the gastric $p H$ of patients with other gastric operations and with gastrocolic fistulae after gastric operation are presented for comparison.

Gastric operations other than Polya partial gastrectomy Bacteriological examination of 14 specimens from 14 patients who had undergone gastric operations other than Polya partial gastrectomy yielded less than $10^{4}$ organisms per gram of juice (Fig. 3). The counts found in this group of patients were slightly higher than those found in normal people and are of the same order as those found in achlorhydric patients.

Gastrojejunocolic fistulae Samples from the jejunum of each of four patients with gastrojejunocolic fistulae were examined (Fig. 4); the samples yielded a complex bile-resistant flora.

Blind loops Jejunal samples from each of two patients with ileal blind loops were cultured; one of these was sterile. The other is presented as the first specimen from patient 2 in Table II; it yielded a complex flora qualitatively similar to that of faeces.

A specimen of jejunal juice was examined from each of 15 patients with duodenal and jejunal diverticulosis (Fig. 5). On bacteriological grounds

TABLE II

$\begin{array}{ll}\text { Patient } & \text { Time since } \\ \text { and } & \text { First } \\ \text { Diagnosis } & \begin{array}{l}\text { Intubation } \\ (w k)\end{array}\end{array}$

EFFECT OF ANTIBIOTICS ON FAECAL_FAT AND SMALL INTESTINAL FLORA IN THREE PATIENTS

Site Sampling
Faecal Fat Antibiotic $(\mathrm{g} / 24 \mathrm{hr}) \quad(1 \mathrm{~g} /$ day $)$

$(w k)$

\begin{tabular}{lllll} 
No. of Organisms per & Gram of Sample & \\
\hline $\begin{array}{l}\text { Entero- } \\
\text { bacteria }\end{array}$ & $\begin{array}{l}\text { Entero- } \\
\text { cocci }\end{array}$ & Yeasts & $\begin{array}{l}\text { Bacter- } \\
\text { oides }\end{array}$ & $\begin{array}{l}\text { Bifido- } \\
\text { bacteria }\end{array}$
\end{tabular}

Free Bile Bacterie Acids Able toD (Present or Hydrole Absent) Bile Acit

\begin{tabular}{|c|c|c|c|c|c|c|c|c|c|c|c|}
\hline 1. Multiple & 0 & Ligament of Treitz & $42 \cdot 3$ & None & $10^{5}$ & $10^{3}$ & $\mathbf{0}$ & $10^{\circ}$ & 0 & Not tested & + \\
\hline small & 1 & Ligament of Treitz & $11 \cdot 0$ & Tetracycline & 0 & $\mathbf{0}$ & $\mathbf{0}$ & 0 & $\mathbf{0}$ & Not tested & - \\
\hline intestinal & 26 & Ligament of Treitz & $11 \cdot 2$ & Tetracycline & $10^{5}$ & 0 & 0 & $10^{8}$ & 0 & Not tested & + \\
\hline diverticulli & 50 & Ligament of Treitz & 21.9 & Tetracycline & $10^{7}$ & 0 & $\mathbf{0}$ & $10^{\circ}$ & $10^{\circ}$ & + & + \\
\hline $\begin{array}{l}\text { 2. Blind loop } \\
\text { of ileum }\end{array}$ & $\begin{array}{r}58 \\
0\end{array}$ & $\begin{array}{l}\text { lleum } \\
\text { Third part of } \\
\text { duodenum }\end{array}$ & $\begin{array}{l}19 \cdot 0 \\
17 \cdot 0\end{array}$ & $\begin{array}{l}\text { Nitrofurantoin } \\
\text { None }\end{array}$ & $\begin{array}{l}10^{7} \\
10^{\circ}\end{array}$ & $\begin{array}{c}0 \\
10^{2}\end{array}$ & $\begin{array}{l}\mathbf{0} \\
\mathbf{0}\end{array}$ & $\begin{array}{l}10^{\circ} \\
10^{\circ}\end{array}$ & $\begin{array}{l}10^{\circ} \\
10^{\circ}\end{array}$ & $\begin{array}{l}+ \\
+\end{array}$ & $\begin{array}{l}+ \\
+\end{array}$ \\
\hline \multirow{5}{*}{$\begin{array}{l}\text { 3. Jejuna! } \\
\text { obstruction, } \\
\text { regional } \\
\text { enteritis }\end{array}$} & $\begin{array}{r}4 \\
30\end{array}$ & Ligament of Treitz & 6.0 & Tetracycline & $10^{\circ}$ & 0 & 0 & $\mathbf{0}$ & $\mathbf{0}$ & - & - \\
\hline & $\begin{array}{r}30 \\
0\end{array}$ & $\begin{array}{l}\text { Ileum } \\
\text { Third part of } \\
\text { duodenum }\end{array}$ & $\begin{array}{l}\text { Not tested } \\
11.0\end{array}$ & $\begin{array}{l}\text { Tetracycline } \\
\text { None }\end{array}$ & $\begin{array}{l}10^{\circ} \\
10^{\circ}\end{array}$ & $\begin{array}{l}0 \\
0\end{array}$ & $\begin{array}{c}0 \\
10^{\circ}\end{array}$ & $\begin{array}{c}0 \\
10^{\circ}\end{array}$ & $\begin{array}{c}10^{\circ} \\
0\end{array}$ & $\frac{+}{-}$ & $\stackrel{+}{\text { Not te }}$ \\
\hline & $\begin{array}{l}0 \\
8\end{array}$ & Ligament of Treitz & $10 \cdot 2$ & None & 0 & 0 & $10^{5}$ & $10^{8}$ & 0 & + & + \\
\hline & 8 & $\begin{array}{l}\text { Third part of } \\
\text { duodenum }\end{array}$ & Not tested & Tetracycline & 0 & 0 & $10^{6}$ & $10^{7}$ & 0 & 一 & + \\
\hline & 9 & $\begin{array}{l}\text { Third part of } \\
\text { duodenum }\end{array}$ & $12 \cdot 5$ & Tetracycline & $10^{\circ}$ & 0 & $10^{\circ}$ & $10^{\circ}$ & $10^{2}$ & - & - \\
\hline
\end{tabular}



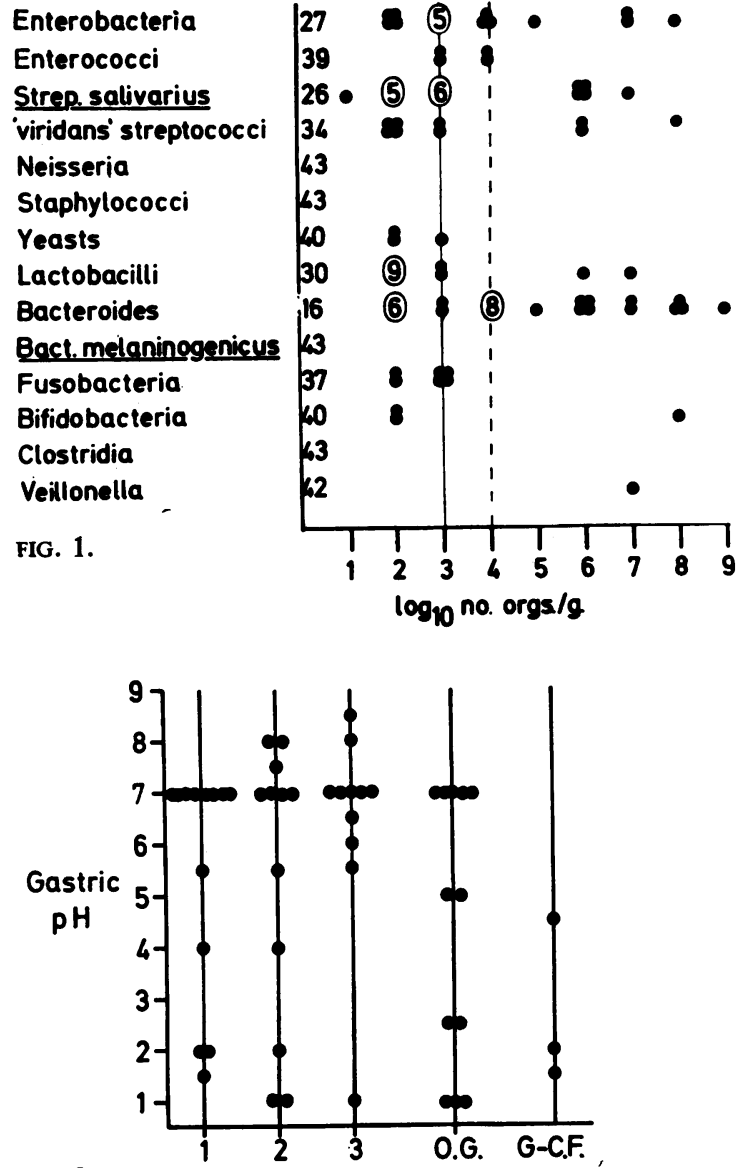

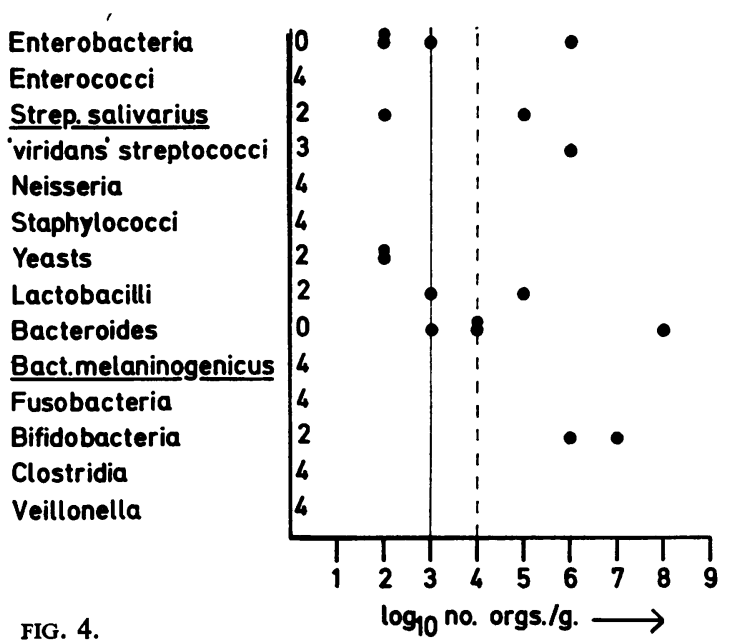

FIG. 1. The bacterial content of 43 samples of jejuna juice from 43 patients with Polya partial gastrectomy. The figures to the left of the diagram represent the number of samples negative for the particular organism. Each spot represents an isolation. The solid vertical line $\left(10^{3}\right)$ indicates the upper level found in fasting normal subjects; the dotted line $\left(10^{4}\right)$ indicates the upper level found in fast ing achlorhydric subjects.

FIG. 2. The gastric $\mathrm{pH}$ found in patients with Polya partial gastrectomy (1, 2, and 3), patients with other gastric operations (O.G.), and patients with gastrojejunocolic fistulae (G-C.F.).

FIG. 3. The bacterial content of 14 samples of jejunal juice from 14 patients who had undergone gastric operations other than Polya partial gastrectomy. The figures to the left of the diagram represent the number of samples negative for the particular organism.

FIG. 4. The bacterial content of four samples from four patients with gastrojejunocolic fistulae. The figures to the left of the diagram represent the number of samples negative for the particular organism. 


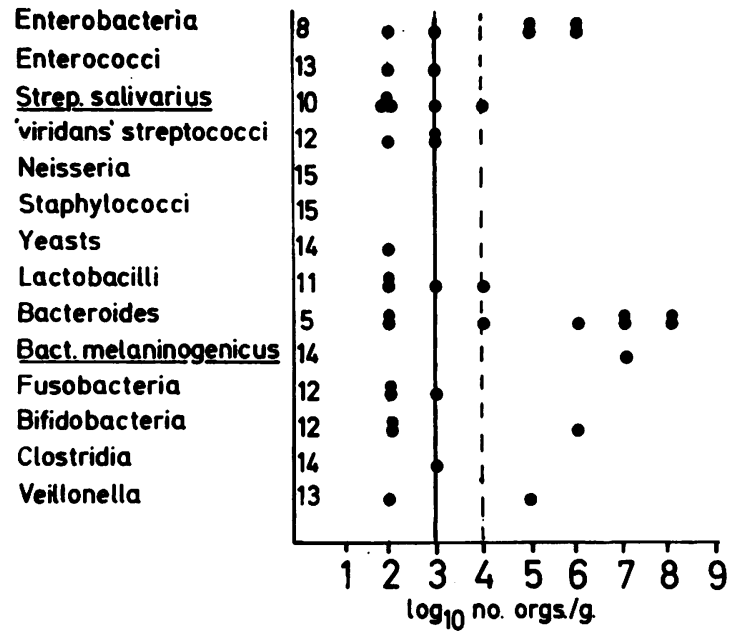

FIG. 5. The bacterial content of 15 samples of jejunal juice from 15 patients with jejunal diverticulosis. The figures to the left of the diagram represent the number of specimens negative for the particular organism.

two groups of patients can be distinguished. One group consisted of seven patients with less than $10^{4}$ bacteria per gram of sample; these patients showed no evidence of an established ecosystem in the upper jejunum. The other group consisted of eight patients with more than $10^{4}$ bacteria per gram of sample; the flora of these samples was complex and bile resistant, thus being indicative of jejunal colonization.

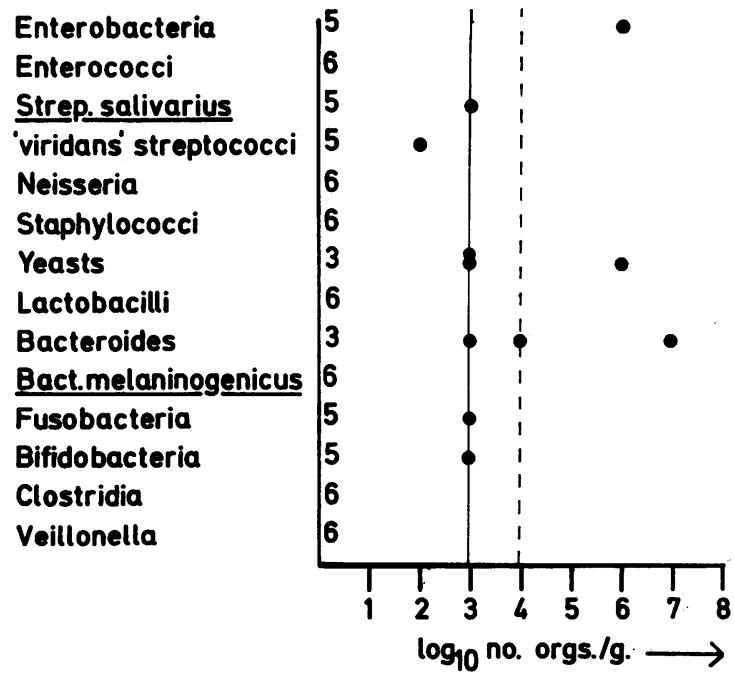

FIG. 6. The bacterial content of six samples of jejunal juice from six patients with regional enteritis. The figures to the left of the diagram represent the number of samples negative for the particular organism.
Regional enteritis Six samples from six subjects with regional enteritis were cultured (Fig. 6). Only one of these, presented in more detail as specimen 1 of patient no. 3 in Table II, showed any abnormal bacteria. The remaining five were similar to samples from normal people.

Pancreatitis Four samples from four subjects with pancreatitis were cultured; three of the samples were sterile, the remaining sample yielded $10^{4}$ Bacteroides per gram. These samples were thus similar to those from normal people.

Diarrhoea Thirteen samples examined were bacteriologically indistinguishable from those of normal subjects. The fourteenth sample from the patient with Strongyloides infection contained $10^{6}$ Enterobacteria and $10^{7}$ Bacteroides per gram.

Coeliac disease and idiopathic steatorrhoea The jejunal juices of the patients showed bacterial growth which was quantitatively and qualitatively similar to that of the control subjects.

BILE SALT DEGRADATION AND FAECAL FAT The faecal fat excretion rates of the patients with Polya partial gastrectomy are presented in Fig. 7 subdivided into three groups on bacteriological grounds. Similar data for the patients who had undergone gastric operations other than Polya partial gasrectomy and for the patients with gastrocolic fistulae are included for comparison. For the two groups of subjects with diverticulosis the data are presented in Figure 8.

There was a suggestion in the data that the patients

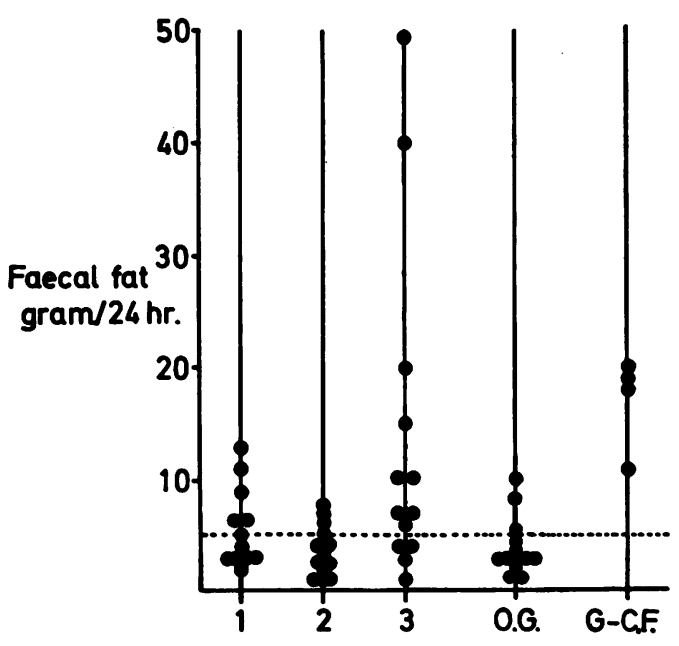

FIG. 7. The faecal fat excretion in patients with Polya partial gastrectomy (groups 1, 2 and 3), patients with other gastric operations (O.G.), and patients with gastrojejunocolic fistulae $(G-C F)$. 


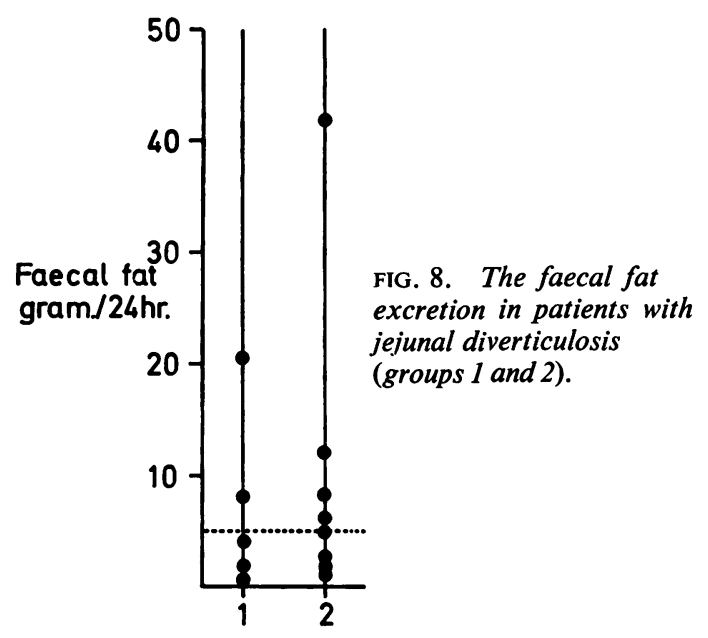

who had diverticulosis or had had a Polya gastrectomy and who had more than $10^{4}$ bacteria per gram excreted more fat than those with lower counts but this difference does not attain statistical significance.

Table III gives the proportion of specimens containing free bile acids and the proportion of specimens from which bacteria able to hydrolyse sodium taurocholate were isolated.

All the bacteria tested from subjects after Polya gastrectomy who had large numbers of bacteria in the jejunal fluid (group 3) and from subjects with diverticulosis similarly colonized (group 2) were able to hydrolyse bile conjugates (Table III). However, some bacteria obtained from the subjects who had had a Polya gastrectomy and who had

\section{TABLE III}

OCCURRENCE OF FREE BILE SALTS AND BACTERIA ABLE TO HYDROLYSE BILE CONJUGATES IN JEJUNAL JUICE

\begin{tabular}{|c|c|c|c|}
\hline Group & $\begin{array}{l}\text { No. } \\
\text { of } \\
\text { Cases }\end{array}$ & $\begin{array}{l}\text { No. of Samples } \\
\text { Containing } \\
\text { Free Bile Salts/ } \\
\text { No. of Samples } \\
\text { Tested }\end{array}$ & $\begin{array}{l}\text { No. of Samples } \\
\text { Containing } \\
\text { Bacteria Able } \\
\text { To Hydrolyse } \\
\text { Bile Acid } \\
\text { Conjugates/ } \\
\text { No. of Samples } \\
\text { Tested }\end{array}$ \\
\hline $\begin{array}{l}\text { Polya partial gastrectomy } \\
\text { (group 1) }\end{array}$ & 16 & $0 / 5$ & $1 / 5$ \\
\hline $\begin{array}{l}\text { Polya partial gastrectomy } \\
\text { (group 2) }\end{array}$ & 14 & $0 / 5$ & $2 / 8$ \\
\hline $\begin{array}{l}\text { Polya partial gastrectomy } \\
\text { (group 3) }\end{array}$ & 13 & $2 / 5$ & $6 / 6$ \\
\hline Other gastric operations & 13 & $0 / 4$ & $0 / 4$ \\
\hline $\begin{array}{l}\text { Gastro-jejuno-colic } \\
\text { fistula }\end{array}$ & 4 & $0 / 0$ & $2 / 2$ \\
\hline Ileal blind loop & 2 & $1 / 2$ & $1 / 1$ \\
\hline Diverticulosis (group 1) & 7 & $1 / 4$ & $3 / 6$ \\
\hline Diverticulosis (group 2) & 8 & $2 / 3$ & $5 / 5$ \\
\hline Regional enteritis & 6 & $0 / 2$ & $1 / 1$ \\
\hline
\end{tabular}

only a few bacteria in the jejunal fluid (group 1) and bacteria obtained from subjects with diverticulosis but no evidence of small intestinal colonization were also able to hydrolyse the conjugates (Table III). About one half of the sample of jejunal juice tested in these two groups (group 3 of Polya partial gastrectomy and group 2 of diverticulosis) contained free bile acids. But compared with the other groups, this represented a much higher proportion of free bile acids.

Since only few bacteria were isolated from the jejunal juices of patients with pancreatitis, nonspecific diarrhoea, coeliac disease, and idiopathic steatorrhoea, no tests of bacterial breakdown of conjugated bile salts were performed. However, of three strains of Bacteroides tested from one patient with Strongyloides infection, all were able to deconjugate bile salts and his jejunal juice contained free bile acids.

In three patients in addition to a pretreatment intubation, several repeat intubations were performed after a course of the antibiotics to which the organisms were found to be sensitive (Table II).

Patient no. 1 suffered from multiple small intestinal diverticulosis. He had three repeat intubations at the level of the ligament of Treitz and one at the level of the ileum, the former after oral tetracycline, $250 \mathrm{mg}$ qid, and the latter after oral nitrofurantoin. Seven days after tetracycline, the jejunal aspirate was sterile but six and 12 months after continuous therapy recolonization had occurred. The bacteria had become resistant to most broad-spectrum antibiotics but were sensistive to nitrofurantoin. Despite the administration of the latter an ileal aspirate showed undiminished growth of bacteria formerly present, and in addition, Clostridia were also cultured. Other tests carried out demonstrated achlorhydria, low tryptic activity after the Lundh test, and steatorrhoea which decreased after antibiotics. Free bile acids were found in the last two aspirates and bacteria isolated from samples $1,3,4$, and 5 were able to hydrolyse sodium taurocholate.

Patient no. 2 had two repeat aspirations, the first, at the level of the ligament of Treitz, and the second, at laparotomy, at a level above an ileal blind loop. Four weeks after continuous tetracycline therapy only Enterobacteria could be cultured from the jejunal aspirates though their numbers reached $10^{6}$. At that time the faecal fats decreased from $17.0 \mathrm{~g}$ to $6.0 \mathrm{~g}$ per 24 hours, and free bile acids found in the aspirates before treatment could not be found any longer. Six months later and still on tetracycline, a profuse growth of Bacteroides $\left(10^{9}\right)$ and Enterobacteria $\left(10^{8}\right)$ was found in the ileal sample above the blind loop, free bile acids were detected, and the Bacteroides were able to hydrolyse. This patient 
was also achlorhydric and his Lundh test showed low tryptic activity.

Patient no. 3 suffered from regional jejunitis with multiple jejunal strictures and resultant subacute small intestinal obstruction. Two pretreatment and two post-tetracycline aspirations were examined, all at the level of the ligament of Treitz. The pretreatment cultures grew only Bacteroides and yeast $\left(10^{5}-10^{6}\right)$. After eight and nine weeks of oral tetracycline there was an increase in the Bacteroides to $10^{7}$ and in addition large numbers of Enterobacteria $\left(10^{6}\right)$ were also grown. However, free bile acids found in one pretreatment sample could no longer be demonstrated in the samples after treatment and the bacteria capable of hydrolysing bile acid conjugates lost this ability in the last sample.

\section{DISCUSSION}

The results of previous investigations on the nature of intestinal colonization cannot be fully accepted in the light of recent advances in bacteriological techniques. Thus it was shown (Drasar, 1967; Lee, Gordon, and Dubos, 1968) that the use of an anaerobic cabinet enhances the yield of anaerobic bacteria manyfold. This is of great importance in the isolation and study of the enzymic properties of Bacteroides, the organism most active in bile salt degradation.

The definition of bacterial colonization of the intestine as distinct from transient contamination is difficult. We consider that the type of bacteria as well as their numbers are important. Thus Streptococcus salivarius, a salivary organism, is often isolated but is unable to grow in the presence of intestinal concentrations of bile salts. As a working hypothesis we adopt the view that, on ecological grounds, small intestinal colonization means a bacterial flora qualitatively resembling that found in the large intestine and faeces (Drasar, 1968). Bacterial colonization may further be defined as the occurrence of a bile salt-tolerant flora consisting of both aerobic bacteria such as Escherichia coli and Streptococcus faecalis and anaerobic bacteria such as Bacteroides and Bifidobacteria.

Our results indicate that patients with regional enteritis and pancreatitis show no consistent colonization of their jejunal juices in the presence or absence of steatorrhoea. Similar results have been obtained in our patients with idiopathic steatorrhoea and coeliac disease before or after treatment with a gluten-free diet. A group of 13 patients with nonspecific diarrhoea but without steatorrhoea similarly showed no colonization with non-pathogenic (or pathogenic) organisms.

Operations that maintain intestinal continuity do not provide opportunities for colonization. Thus our patients who had undergone operations, such as Billroth I partial gastrectomy, resulting in gastric achlorhydria but no blind loop, yielded specimens bacteriologically similar to those obtained from subjects with achlorhydria due to gastric mucosal atrophy (Drasar, Shiner, and McLeod, 1969). By way of contrast the patients in our series yielding the highest counts of bacteria, leaving aside those with fistulae, were those who had an anatomical blind loop or had had a Polya partial gastrectomy. Such 'blind loops' thus become a source of continual contamination of the small intestine.

Our results in the 'blind loops' presented here suggest a correlation between the colonization of large numbers of anaerobes possessing bile deconjugating enzymes and the presence of free bile acids in the jejunal juice of these patients but not with steatorrhoea. The decrease in concentration of conjugated bile salt rather than an increase of free bile acids in the jejunum may be the important factor for the mechanism of steatorrhoea (Tabaqchali, Hatzioannou, and Booth, 1968). Tabaqchali et al (1968) further suggested that the site and extent of the blind loop was important. However Goldstein, Cozzolino, and Wirts (1963) reported a case with a solitary duodenal diverticulum associated with steatorrhoea, and we have confirmed this.

Two patients in the present series presenting as stagnant loop syndrome (patients 1 and 2, Table II) had a dramatic, though short-term, response to antibiotics associated in one case with the disappearance of free bile acids and bile acids deconjugating bacteria from the jejunum.

From this study it is apparent that jejunal colonization may occur without overt signs or symptoms. The long-term impact of this abnormal flora on bile metabolism is unknown, but the determining factor may be the total mass of those bacteria able to hydrolyse bile salts.

We wish to thank Mrs E. Cox and Miss J. Lambert for their invaluable assistance. B. S. Drasar is in receipt of a grant from the Medical Research Council.

\section{REFERENCES}

Dawson, A. M., and Isselbacher, K. J. (1960). Studies on lipid metabolism in the small intestine with observations on the role of bile salts. J. clin. Invest., 39, 730-740.

Drasar, B. S. (1967). Cultivation of anaerobic intestinal bacteria. J. Path. Bact., 94, 417-427.

(1968). Studies on the intestinal flora. Thesis, London University. Hill, M. J., and Shiner, M. (1966). The deconjugation of bile salts by human intestinal bacteria. Lancet, 1, 1237-1238.

- Shiner, M., and McLeod, G. M. (1969). Studies on the intestinal flora. I. The bacterial flora of the gastrointestinal tract in 
healthy and achlorhydria persons. Gastroenterology, 56, 71-79.

Goldstein, F., Cozzolino, H. J., and Wirts, C. W. (1963). Diarrhea and steatorrhea due to a large solitary duodenal diverticulum. Amer.J. dig. Dis., 8, 937-943.

Hill, M. J., and Drasar, B. S. (1968). Degradation of bile salts by human intestinal bacteria. Gut, 9, 22-27.

van de Kamer, J. H., ten Bokkel Huinink, H., and Weyers, H. A. (1947). Rapid method for determination of fat in feces. J. biol. Chem., 177, 347-355.

Lee, A., Gordon, J., and Dubos, R. (1968). Enumeration of the oxygen sensitive bacteria usually present in the intestine of healthy mice. Nature (Lond.), 220, 1137-1139.

Shiner, M. (1963). A capsule for obtaining sterile samples of gastrointestinal fluids. Lancet, 1, 532-533.

Tabaqchali, S., Hatzioannou, J., and Booth, C. C. (1968). Bile-salt deconjugation and steatorrhoea in patients with the stagnantloop syndrome. Lancet, 12-16.

Wirts, C. W., Templeton, J. Y., III, Fineberg, C., and Goldstein, F. (1965). The correction of postgastrectomy malabsorption following a jejunal interposition operation. Gastroenterology, 44, 141-149. 